\title{
"Unirse desde abajo": O discurso terceiromundista da CGT de los Argentinos e os limites da ortodoxia peronista
}

Karolline Pacheco Santos ${ }^{1}$

\begin{abstract}
Resumo: A perspectiva "terceiromundista" foi uma tendência política que se consolidou no discurso revolucionário latino-americano no contexto das ditaduras das décadas de 1960 e 1970. A partir das críticas desenvolvidas pelo teórico argentino Juan José Sebreli a respeito do caráter mítico burguês da ideia de Terceiro Mundo para o processo revolucionário, buscou-se traçar a relação entre as ponderações levantadas pelo autor com a experiência vivenciada pelos trabalhadores argentinos radicalizados em torno da CGT de los Argentinos. Entre os pontos de convergência e divergência no plano discursivo, chegou-se à conclusão de que a cultura política peronista, predominante entre os trabalhadores, confirmava os limites do discurso nacionalista; contudo, a análise do teórico não abarcava a realidade política destes trabalhadores que revelaram outros desdobramentos na lógica discursiva da abordagem terceiromundista.
\end{abstract}

Palavras-chave: Terceiro Mundo, sindicalismo argentino, peronismo, CGT de los Argentinos.

\section{"Unirse desde abajo": The third world speech from de "los Argentinos" General Confederation of Labour and the limits of peronist orthodoxy}

\begin{abstract}
The "Third World" perspective was a political trend which consolidated itself in Latin American revolutionary discourse in the context of the dictatorships of the 1960s and 1970s. Based on the criticism developed by the Argentinean thinker Juan José Sebreli on the mythical bourgeois character of the idea of a Third World for the revolutionary process, we have sought to explore the relationship between this author's contributions with the experience of radicalized Argentinean workers around the $C G T$ de los Argentinos. Analyzing points of convergence and divergence in the discursive realm, it is possible to come to the conclusion that peronist political cultural, which was predominant among workers, confirmed the limits of nationalist discourse; however, Sebreli's analysis did not take into account the political reality of these workers, which revealed other ramifications of the discursive logic of the "Third World" approach.
\end{abstract}

Keywords: Third World, Argentinean unionism, peronism, CGT de los Argentinos.

Artigo recebido em: 28/07/2016

Artigo aprovado em: 05/07/2017

\footnotetext{
${ }^{1}$ Bacharel e licenciada em História pela Universidade de Brasília(UnB) e mestre pelo programa de pósgraduação em História da UnB na área de Política, Instituições e relações de poder. E-mail: karolline_santos@hotmail.com
}

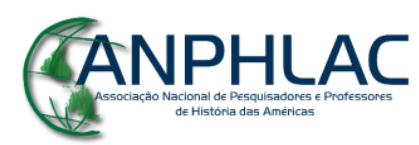

Revista Eletrônica da ANPHLAC, ISSN 1679-1061, №. 23, p. 238-260, Jul./Dez., 2017. http://revista.anphlac.org.br 


\section{Introdução}

A América Latina, durante as décadas de 1960 e 1970, foi cenário de importantes movimentos sociais radicalizados que construíram seus discursos políticos a partir de conceitos como "libertação nacional", "anti-imperialismo", "revolução social", "independência econômica" entre outros. A constância destes conceitos em discursos políticos que se originavam da direita nacionalista à esquerda revolucionária revela alguns traços da cultura política regional em que o imaginário anti-imperialista foi, com frequência, a chave-explicativa para traduzir as influências da conjuntura internacional $^{2}$. Como cultura política, conceito central para a construção dos discursos políticos, partiu-se da definição de Serge Berstein (1998) que o define como um conjunto de práticas coerentes “[...] em que todos os elementos estão em estreita relação uns com os outros, permitindo definir uma forma de identidade do indivíduo que dela se reclama" (BERSTEIN, 1998, p. 355). Além disso, um dos fatores que condicionam o conceito de cultura política é seu caráter plural, em um dado espaço e tempo, sendo este central para compreender a convivência e articulação de diferentes culturas políticas que se relacionam, interagem e se redefinem a partir de pontos de contato.

Ao final dos anos 1960, os movimentos de libertação nacional dos continentes africano e asiático influenciaram a construção do conceito de Terceiro Mundo, que agregaria países de diferentes regiões e formações sociais. Levantando a bandeira da "libertação nacional", consolidavam-se os princípios de autoafirmação dos povos, seja pela conquista tardia da independência política dos países ainda colonizados, seja pelo viés da independência econômica dos países subdesenvolvidos. Este ideário embalou movimentos revolucionários no continente e constituiu um filtro ideológico que caracterizou um discurso que se contrapunha ao capitalismo, representado na luta contra os monopólios econômicos e o capital estrangeiro, e ao socialismo internacionalista, considerado uma forma de coletivismo totalitário e ateu. Conformando um possível sistema político, social e econômico original propunha-se uma terceira via identificada

\footnotetext{
2 “'(..) la posibilidad de pensar al antiimperialismo como una sensibilidad subyacente o como un gran telón de fondo inescapable, sino para todas, al menos para algunas familias doctrinarias e ideológicas. Este modo de enfocar el tema habilitaría a pensar el antiimperialismo como un imaginario particular e, incluso, más ampliamente, como una de las dimensiones del imaginario social, colocándolo en relación estrecha con núcleos de significaciones socialmente decisivas" (KOZEL; GROSSI; MORONI, 2015, p. $13)$.
}

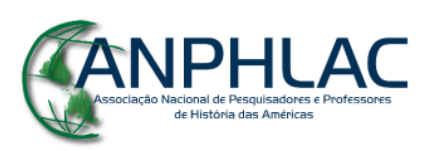

Revista Eletrônica da ANPHLAC, ISSN 1679-1061, №. 23, p. 238-260, Jul./Dez., 2017. http://revista.anphlac.org.br 
como "socialismo nacional" que encontrou no continente latino-americano terra fértil em sua já tradicional cultura política fortemente cristã e nacionalista/anti-imperialista.

A radicalização de diversos segmentos da sociedade latino-americana por um caminho de mudanças revolucionárias na segunda metade do século XX assimilou, em muitos casos, este discurso "terceiromundista". Essa ampla difusão produziu conflitos com outros segmentos radicalizados da sociedade adeptos à esquerda marxista e importantes debates que nos levam a compreender as tensões existentes nos projetos revolucionários da época. A partir da obra do argentino Juan José Sebreli, que publicou em 1975 o livro Tercer Mundo, mito burguês, a crítica ao viés nacionalista burguês do discurso terceiromundista sustentava a tese na qual a fase imperialista não havia substituído a luta de classes pela luta entre nações e que a fragilidade do conceito de “Terceiro Mundo" se justificava, pois “(...) sobre una serie de fenómenos sociales y económicos con ciertas analogias, se ha colocado una etiqueta que permite simplificar una realidade llena de contradicciones y antagonismos" (SEBRELI, 1975, p. 33). O autor buscou abordar como fascistas certas características do discurso e salientou a inviabilidade de uma "internacional nacionalista", contradição conceitual representada pelo caminho do "socialismo nacional” (SEBRELI, 1975, p. 32). O sociólogo argentino advertia sobre o caráter reacionário de substituir a classe trabalhadora como agente histórico e, logo, afirmava a centralidade dos trabalhadores neste processo contra a entidade monolítica que representava a ideia de povo/nação onde se empurrava para debaixo do tapete as contradições sociais.

Em contrapartida, a experiência do sindicalismo radicalizado na Argentina, organizado em torno da dissidência da Central General del Trabajo (CGT) conhecida como CGT de los argentinos (CGTA), foi um caso exemplar da classe trabalhadora organizada que buscou pensar a revolução a partir do "Terceiro Mundo"; o movimento ao redor da CGTA foi um dos pontos de partida para as diferentes organizações armadas que engrossaram os conflitos na Argentina a partir da década de 1970 (BARTOLETTI, 2011). A partir da CGTA, pretende-se compreender as construções simbólica da classe trabalhadora revolucionária em torno deste ideal de revolução e do seu papel por meio da análise do discurso do Semanário CGT. Este foi lançado em $1^{\circ}$ de maio de $1968 \mathrm{com}$ a função de informar e formar politicamente os trabalhadores; foram publicados no total

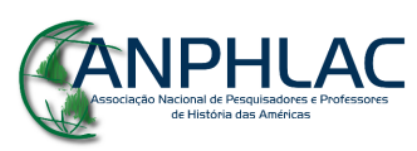

Revista Eletrônica da ANPHLAC, ISSN 1679-1061, №. 23, p. 238-260, Jul./Dez., 2017. http://revista.anphlac.org.br 
55 números entre maio de 1968 e fevereiro de 1970. De acordo com a historiadora Luciana Sotelo (2008, p. 8):

\begin{abstract}
Su lenguaje introducía tonos que no eran habituales en el léxico de los sindicalistas, y si bien el discurso central se dirigía al movimiento obrero, el semanario daba espacio destacado a la lucha de los universitarios y presentaba a los nuevos sujetos sociales que se afirmaban en la resistencia a la dictadura de la 'Revolución Argentina': villeros, pobladores del interior del país, sacerdotes del tercer mundo.
\end{abstract}

As divergências e possíveis encontros entre a crítica ao "terceiromundismo" empreendida pelo intelectual argentino e a realidade da ação política preconizada pela classe trabalhadora organizada na CGTA são os objetivos desta breve explanação.

\title{
Libertação Nacional versus Revolução Socialista
}

A expressão "Terceiro Mundo", cunhada pelo sociólogo francês Alfred Sauvy, consagrou-se no meio intelectual como forma de identificar uma imensa zona de países cuja questão primordial não estava em se alinhar com uma ou outra potência mundial do campo político surgido após 1945, mas em exprimir uma terceira via ao imperialismo representado tanto pelos Estados Unidos como pela União Soviética. Para muitos destes países, a primazia da ideia de "libertação nacional" encontrava respaldo na condição colonial de alguns deles e na dependência econômica que caracterizava uma espécie de novo colonialismo para nações politicamente independentes. $\mathrm{Na}$ Conferência de Bandung (1954), países africanos e asiáticos institucionalizaram a opção pelo "nãoalinhamento" e a noção de "autodeterminação dos povos", que ganhou força na América Latina a partir do sucesso da experiência cubana em 1959. A alternativa ao modelo soviético correspondeu a uma reconfiguração dos laços que envolviam a esquerda colocando em primeiro plano os projetos de solidariedade entre esses países que passavam a se situar geopoliticamente como "Terceiro Mundo". O eixo de tensão nas relações internacionais se deslocava do conflito Ocidente-Oriente para outro com foco mais difuso, o conflito entre Norte-Sul. A posição não respondia a escolha de um dos modelos preexistentes, mas a tentativa nacional de um modelo economicamente mais justo.

\section{GANPHLAC}

Revista Eletrônica da ANPHLAC, ISSN 1679-1061, №. 23, p. 238-260, Jul./Dez., 2017.

http://revista.anphlac.org.br 
Na obra de Juan Jose Sebreli, a primeira objeção desenvolvida é a própria definição do conceito:

El Tercer Mundo no es una realidad objetiva, no es una categoría histórica, no es sino una figura ideológica (...) sustentada por los sectores pequeñoburgueses radicalizados de los países dependientes, no es tampoco una doctrina unificada y coherente, abarca distintas concepciones que pasando por la posición de algunos sectores del clero posconciliar, van desde un semifascismo en su ala derecha hasta un semimarxismo en su ala izquierda. (SEBRELI, 1975, p. 33)

Para o autor, o conceito é falho, pois desconsidera desigualdades e conflitos internos a este pretenso terceiro bloco e cujos laços em comum eram muito superficiais para se falar na base de uma solidariedade entre países. ${ }^{3}$

No caso latino-americano, a consolidação da Teologia da Libertação, movimento progressista da Igreja Católica embasado pela encíclica papal Populorum Progressio (março/1967), impulsionou o discurso terceiromundista rumo às principais tradições culturais do discurso político da região, o catolicismo e o anti-imperialismo; a mudança das condições políticas dos povos oprimidos era um dever cristão; e a leitura marxista o transformava também em uma necessidade histórica, delimitando a ideia de "Terceiro Mundo":

\begin{abstract}
Los pueblos del Tercer Mundo forman el proletariado de la humanidad actual, explotados por los grandes y amenazados en su existencia misma por los que, solo por ser los más fuertes, se arrogan el derecho de ser los jueces y los policías de los pueblos materialmente menos ricos. (...) Los cristianos y todos los hombres de buena voluntad no pueden más que adherirse a este movimiento, incluso si tienen que renunciar a sus privilegios y a sus fortunas personales, en beneficio de la comunidad humana en una socialización más grande. (Manifesto dos Bispos do Terceiro Mundo, 1968)
\end{abstract}

No "Manifesto dos Bispos do Terceiro Mundo", há um recorte geográfico assinam bispos do Brasil, Argélia, Oceania, Egito, Colômbia, Iugoslávia, Líbano,

\footnotetext{
3 Para Sebreli, inclusive a possibilidade de o "Terceiro Mundo" se constituir em um bloco com capacidade de interferência no sistema internacional a partir da "terceira posição", preconizada por Juan D. Perón na Argentina, ou da "neutralidade" no campo político, eram inviáveis, "(...) Asia, África y América Latina no han podido constituir un verdadero bloque político homogéneo y muchos de ellos están profundamente desgarrados por conflictos de intereses" (SEBRELI, 1975, p. 26).

${ }^{4} \mathrm{O}$ movimento se iniciou quando dezoito bispos encabeçados pelo monsenhor brasileiro Dom Helder Câmara, bispo de Recife, tornaram público este documento na Conferência Episcopal Latino-americana, em 1968, na cidade de Medellín, Colômbia. Na Argentina, o movimento começou com 270 sacerdotes, número que depois passou a 400, que aderiram publicamente ao manifesto começando a gestar a faceta
}

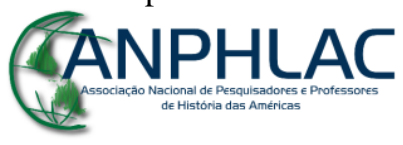

Revista Eletrônica da ANPHLAC, ISSN 1679-1061, №. 23, p. 238-260, Jul./Dez., 2017. http://revista.anphlac.org.br 
Cingapura, Laos e Indonésia - e uma definição dos laços de solidariedade que se embasava no sentimento comum de povos oprimidos e pobres “(...) que se esfuerzan y luchan por su desarrollo" em um argumento que tem como origem do mal o sistema econômico. Como "proletariado de la humanidad" o "Terceiro Mundo", em uma tradução marxista, tornava-se o agente histórico por primazia em levantar a revolução socialista e construir uma ordem mundial mais justa. Por este discurso, criou-se uma solidariedade entre nações oprimidas que superava a solidariedade de classe, já que inclusive trabalhadores de países avançados poderiam ser exploradores dos trabalhadores de países subdesenvolvidos por meio da "lei do intercambio desigual" adotada pelos terceiromundistas ${ }^{5}$. A transposição da luta de classes para o conflito entre nações é, para o sociólogo argentino, uma das armadilhas do "Terceiro Mundo", cuja base nacionalista distorcia os princípios da revolução social e que “(...) usan al marxismo como justificación teórica del apoyo a las burguesias nacionales" (SEBRELI, 1975, p. 113).

Ao sustentar a tese imperialista na qual o subdesenvolvimento era a chave da exploração, criava-se uma empatia entre classe trabalhadora e burguesia nacional que, juntas, deveriam frear os avanços do capital estrangeiro por meio do impulso à industrialização de base nacional, colocando lado a lado trabalhador e patrão. Não se questionava o sistema capitalista - partia-se do pressuposto de que o imperialismo era algo distinto do capitalismo - nem as origens desta exploração. A observação do autor é que, pelo contrário, "El imperialismo (...) al unificar el mundo por la difusión del sistema capitalista hasta el último rincón, universaliza la contradicción entre capital y trabajo, planteando la revolución socialista a escala mundial" (SEBRELI, 1975, p. 34). Não caberia então espaço para "socialismos nacionais"; a ideia de "Terceiro Mundo" seria mais outra estratégia burguesa de obstaculizar a revolução socialista e a conscientização de classe dos trabalhadores; "No tienen derecho a hablar de imperialismo quienes no quieren hablar de capitalismo" (SEBRELI, 1975, p. 196). Em uma explanação a respeito das origens do nacionalismo romântico alemão e italiano,

argentina deste movimento pós-conciliar conhecido como Movimiento Sacerdotes del Tercer Mundo (BALVE; BALVE, 1989).

5 “Los obreros de los países desarrollados pueden gozar de salarios más altos porque la disminución de la plusvalía es compensada con la plusvalía extraída de los países subdesarrollados a través del 'intercambio desigual"” (SEBRELI, 1975, p. 192).

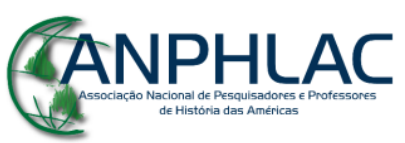

Revista Eletrônica da ANPHLAC, ISSN 1679-1061, №. 23, p. 238-260, Jul./Dez., 2017. http://revista.anphlac.org.br 
Sebreli discorre sobre as similaridades deste com o nacionalismo difundido pelas correntes terceiromundistas. Características em comum como a ênfase na ideia políticojurídica do Estado substituído pelo "povo", o culto à tradição, à terra, aos heróis e grandes individualidades condutoras das massas eram vistas pelo autor como sinais de uma “(...) deformación que sufre el movimiento obrero de nuestros días”; que ao delegar ao Estado o papel revolucionário prescindia da necessidade de que a classe trabalhadora tomasse efetivamente o poder, o que justifica também a crítica à convergência entre a revolução socialista e o Estado peronista no caso argentino.

Fator de desmobilização, a fantasia terceiromundista da passagem do nacionalismo ao socialismo encerrava ainda o tom reformista caracterizado pelo “capitalismo de Estado". Por mais que a algumas vertentes das esquerdas latinoamericanas tentassem engendrar o princípio de "socialismo nacional" em suas revoluções, Sebreli (1975, p. 95) reitera mais uma vez que “(...) no puede hablarse de socialismo en tanto no se plantee la modificación de las relaciones de producción". A confusão entre nacionalização e socialização era uma frequente no discurso terceiromundista que para o autor pleiteava mais uma espécie de justiça social, em que haveria ainda pobres e ricos, ao invés de uma revolução social: "Para el obrero es exactamente igual ser explotado por el Estado o por la burguesía" (SEBRELI, 1975, p. 96).

Somado aos problemas decorrentes do nacionalismo burguês para a revolução socialista estava a crítica mais reiterada sobre os movimentos "populistas" que viraram bandeira das esquerdas latino-americanas adeptas ao "socialismo nacional": o caráter fascista de seus princípios. A crítica assentada na analogia com os nacionalismos alemão e italiano não impediu o autor de negar o tom fascista do peronismo, por exemplo, considerando-o mais como um "bonapartismo de direita" ${ }^{6}$ do que um regime fascista de fato. Todavia, não excluiu a advertência acerca da ligação entre o tom adotado pelo nacionalismo terceiromundista e as nefastas possibilidades de, no futuro, decaírem para as posições fascistas:

\footnotetext{
${ }^{6} \mathrm{Em}$ contraposição à tese terceiromundista de que o "socialismo nacional" seria um modelo político, econômico e social inteiramente novo, Juan J. Sebreli se opõe ao afirmar que este tipo de fenômeno político já havia sido analisado pela teoria marxista como cesarismo, bonapartismo e o nacionalismo burguês. Para o autor, "en tanto que el stalinismo y la socialdemocracia argentina, por su falta de tradición marxista, fueron incapaces de interpretar correctamente al peronismo como bonapartismo y lo confundieron con el fascismo" (SEBRELI, 1975, p. 80).
}

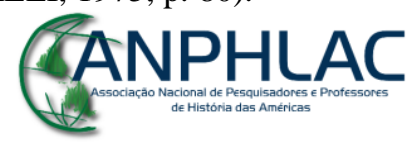

Revista Eletrônica da ANPHLAC, ISSN 1679-1061, №. 23, p. 238-260, Jul./Dez., 2017. http://revista.anphlac.org.br 
El ejemplo de como, en los elevados orígenes del nacionalismo romántico de Alemania e Italia, a pesar del humanismo y del democratismo, ya estaban prefiguradas las tendencias reaccionarias que luego degenerarían en el nazismo y el fascismo, constituye una advertencia acerca de las posibilidades latentes en la ideología nacionalista del Tercer Mundo de nuestros días (...) Frantz Fanon es el Marzzini o el Herder del Tercer Mundo. (SEBRELI, 1975, p. 45)

Para o autor de Tercer Mundo, mito burguês as teorias conhecidas como terceiromundistas não tinham nada de novo e nem de original. Pelo contrário, retomavam princípios de um nacionalismo burguês que tendia a ser reacionário diante dos desafios da classe trabalhadora e contraproducentes como prática revolucionária. Para Sebreli, ao publicar o livro em 1975, ano anterior ao golpe militar que iniciou o Processo de Reorganização Nacional na Argentina, o contexto de escalada da violência política no país com grupos revolucionários adeptos às posições terceiromundistas e o alento dado por governos como o retorno de Perón à Argentina e Salvador Allende no Chile, em 1973, exigiam a análise do caráter ilusório deste discurso e suas limitações como um caminho, de fato, revolucionário. Em tom de advertência, fazia-o a fim de analisar as fragilidades teóricas dessa tendência que vinha embasando as lutas da esquerda na América Latina:

(...) siguen ejerciendo una gran atracción en amplios sectores populares y especialmente en las jóvenes generaciones, en los elementos radicalizados de la pequeña burguesía que corren el riesgo de ser apartados de la verdadera lucha revolucionaria desviándose hacia un callejón sin salida. (SEBRELI, 1975 , p. 75)

Pautando estas críticas desenvolvidas por Juan J. Sebreli, pretende-se agora analisar como, no movimento trabalhista - o ator histórico por excelência da revolução marxista -, articulou-se o pensamento terceiromundista; e em que pontos as ponderações do intelectual argentino se confirmam a respeito desta tendência; e onde a ação política revela outra dimensão.

\section{A CGT de los Argentinos}

O surgimento da CGT de los Argentinos (CGTA) aconteceu durante o governo militar de Juan C. Onganía (1966-1970), um dos artífices da "Revolução Argentina" 
que derrotou o presidente Arturo Illia (1962-1966) em um golpe que foi acompanhado por amplo consenso social, inclusive dos sindicatos, majoritariamente peronistas. Após o fracasso do plano de luta contra o governo lançado em 1967, divergências internas ao campo gremial levaram à divisão da histórica central sindical argentina, em 1968, após a realização de um Congresso Normalizador. A cisão ocorreu entre aqueles que permaneceram em uma linha de participação e negociação com o governo militar de Onganía e aqueles que, afirmando a ilegitimidade do governo, adotaram um tom "combativo" e contestador da nova ordem instituída (DAWYD, 2011). O nascimento da CGTA é documentado por seu programa político Programa $1^{\circ}$ de mayo - Mensaje a los trabajadores y al pueblo argentino publicado no $\mathrm{n}^{\circ} 1$ do Semanário CGT, periódico da central sindical que, de acordo com o secretário geral, Raimundo Ongaro, serviria como “(...) un medio de información y esclarecimiento, pero también y sobre todo [como] un factor de organización"7.

O impacto político da CGTA na trajetória do sindicalismo peronista pós- $1955^{8}$ foi o retorno das lutas trabalhistas para a rua (ROTONDARO, 1971). Desde o período de reorganização do peronismo proscrito sob a Resistencia, a repressão política de governos antiperonistas impulsionou as correntes mais "brandas" do movimento que buscavam o diálogo em detrimento das estratégias de confronto (DAWYD, 2011). A mudança das condições internas após 1966, com o fechamento e controle dos meios de participação política (proibição dos partidos políticos, intervenção nos sindicatos, repressão nas universidades entre outras medidas que caracterizaram um "choque autoritário") e, em especial, com as mudanças econômicas (planos de racionalização que resultaram no fechamento de fontes de trabalho, congelamento de salários e aumento da desocupação), foram o estopim para uma maior radicalização nos enfrentamentos contra a ditadura. Fazendo convergir a resistência de diferentes setores que foram atingidos pela intransigência do governo militar, a CGTA liderou um movimento amplo que desde o programa de $1^{\circ}$ de maio marcou os limites deste conflito e definiu a quem se dirigia:

\footnotetext{
${ }^{7}$ Semanário CGT n ${ }^{\circ} 33,12 / 12 / 1968$.

${ }^{8}$ Em 1955, ocorreu a Revolução Libertadora, golpe responsável por derrocar o então presidente Juan Domingo Perón, levando-o ao exílio e a Argentina a um longo processo de instabilidade política derivada da proscrição do Partido Peronista.
}

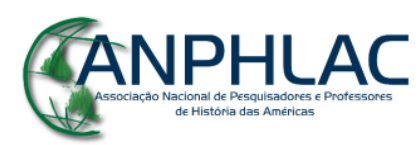

Revista Eletrônica da ANPHLAC, ISSN 1679-1061, №. 23, p. 238-260, Jul./Dez., 2017. http://revista.anphlac.org.br 
La CGT convoca en suma a todos los sectores, con la única excepción de minorías entregadoras y dirigentes corrompidos, a movilizarse en los cuatro rincones del país para combatir de frente al imperialismo, los monopolios y el hambre. ${ }^{9}$

A "central rebelde" surgiu em um momento em que o conflito entre as tendências sindicais se tornou mais agudo - conflito que vinha se manifestando desde a proscrição do peronismo em 1955 - e significou uma renovação no campo das reivindicações trabalhistas e no papel da classe trabalhadora diante do contexto de fechamento político da Revolução Argentina. Ao definir o combate contra os monopólios como eixo principal do conflito, entendia a penetração estrangeira como cerne de todos os demais problemas que assolavam os argentinos e, em especial, os trabalhadores. A penetração estrangeira, no viés de um discurso anti-imperialista, era a chave explicativa para uma ditadura liberal que atropelava os interesses nacionais e tinha como suporte o engessamento do movimento trabalhista através de lideranças sindicais burocratizadas e a serviço de "minorias entreguistas". Ao se dirigir ao povo argentino, a CGTA se inseria em uma perspectiva terceiromundista com a qual era vista como “(...) expresión más alta de um sindicalismo de liberación”" 10 , afirmando que:

(...) las masas trabajadoras argentinas abrazan la causa de la liberación nacional, que en medio del actual colapso del ordenamiento imperialista mundial, agita a todos los pueblos espoliados de Iberoamerica, Asia y Africa. ${ }^{11}$

Na luta que "(...) agita a todos los pueblos espoliados de Iberoamerica, Asia y Africa" a CGTA aderia explicitamente a uma luta que não era apenas dela, senão de outros "povos oprimidos" cujo caminho da "libertação nacional" era a saída contra a exploração imperialista. Frente aos modelos europeus que disputavam espaço no pósguerra, o discurso de superação do subdesenvolvimento se tornou uma saída frente aos dois gigantes imperialistas originando uma forma híbrida conhecida como "socialismo nacional". A CGTA se inseriu abertamente em uma corrente que pensava a Argentina como parte deste imenso bloco de países que, sob a lente do subdesenvolvimento, pensava seu atraso econômico e sua debilidade política:

\footnotetext{
${ }^{9}$ Semanário CGT n ${ }^{\circ} 01,01 / 05 / 1968$.

${ }^{10}$ Semanário CGT n ${ }^{\circ}$ 01, 01/05/1968.

11 Semanário CGT n ${ }^{\circ} 01,01 / 05 / 1968$.
}

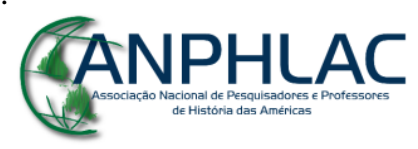

Revista Eletrônica da ANPHLAC, ISSN 1679-1061, №. 23, p. 238-260, Jul./Dez., 2017.

http://revista.anphlac.org.br 
El fin del colonialismo y el derecho imprescriptible de los países sojuzgados a convertirse en nacionalidades libres. Es este el acontecimiento más grande del siglo veinte, y la Argentina como lo ha destacado Juan Domingo Perón no escapa a este destino histórico común que hoy concita a todos los pueblos avasallados de la tierra. ${ }^{12}$

O argumento colonialista é usado reiteradamente para marcar a concepção do subdesenvolvimento como uma consequência direta da exploração europeia original e da "nova" exploração em sua fase imperialista. Abarcava um tom enfático que colocava as contemporâneas lutas pela "libertação nacional" no mesmo rol de dever nacional que era preenchido pelas guerras de independência contra a dominação espanhola e, no caso argentino, contra a Inglaterra: “Al unir a ambas épocas, se destaca la continuidad de la lucha nacional del pasado y del presente" ${ }^{\prime 3}$. Em contrapartida, para consolidar essa "nova fase" de libertação, o próprio governo de Juan C. Onganía era associado a governos oligárquicos anteriores que, em uma história profundamente dualista e marcada pelo revisionismo histórico, ditava o tom conflitivo deste discurso entre oligarquia e povo: “(...) la lucha del pueblo argentino contra sus enemigos de hoy y siempre: la oligarquía y el imperialismo" ${ }^{\prime 14}$.

O tom deste critério de abordagem - a condição de países colonizados e, logo, subdesenvolvidos - é combatido por Juan J. Sebreli (1975, p. 23) em sua crítica à própria conformação do conceito de "Terceiro Mundo": “(...) se incurre en una peligrosa confusión cuando se mezcla a todos los países del llamado Tercer Mundo bajo la denominación común de "colonialismo"”; as diferentes modalidades de colonialismo corresponderam a dinâmicas diversas que não foram comuns aos países dos três continentes. Mais à frente, diante do argumento desenvolvimentista, observava que:

\footnotetext{
Siguiendo una tradición olvidada del marxismo clásico, nos proponemos mostrar que, al contrario de las tesis tercermundistas, no existe una correlación directa entre colonialismo y subdesarrollo. El imperialismo no es la causa del estancamiento de algunos pueblos, sino el estancamiento previo la causa de la caída de ciertos pueblos bajo el imperialismo. Los pueblos son colonizados porque son colonizables. (SEBRELI, 1975, p. 146)
}

A Argentina, por um lado, apresentava características de país desenvolvido com maioria da população urbana, índice de analfabetismo baixo em comparação a outros

\footnotetext{
${ }^{12}$ Semanário CGT n ${ }^{\circ}$ 40, 06 a 20/03/1968.

${ }^{13}$ Semanário CGT n ${ }^{\circ} 40,06$ a 20/03/1968.

${ }^{14}$ Semanário CGT n 20, 12/09/1968.
}

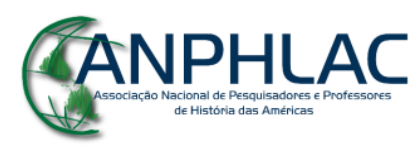

Revista Eletrônica da ANPHLAC, ISSN 1679-1061, №. 23, p. 238-260, Jul./Dez., 2017. http://revista.anphlac.org.br 
países e uma classe média extensa e, por outro lado, tinha altas taxas de desigualdade social e acentuada dependência energética e tecnológica que a colocava no balaio de países subdesenvolvidos.

Além do problema de ordem conceitual, tentativa de encontrar um denominador comum que aglutinasse e orientasse realidades tão díspares, para o intelectual argentino, essa orientação nacionalista da revolução social abandeirada pelos terceiromundistas, trazia no bojo uma armadilha. A advertência era a respeito da confiança exagerada deste nacionalismo de esquerda nas burguesias nacionais como parte de um programa "desenvolvimentista" e a consequente subordinação da luta de classes à luta pela libertação, reduzindo os conflitos sociais a uma luta essencialmente nacional contra um inimigo externo:

\begin{abstract}
El nacionalismo burgués de los países dependientes está interesado en mostrar que el imperialismo es un fenómeno de dependencia externa impuesta a los pueblos sometidos desde afuera y por la fuerza. Por lo tanto, todas las clases nacionales - burguesía o proletariado - constituirían un solo bloque homogéneo, - el pueblo o la nación - interesado en romper con la dependencia mediante una política independiente y el desarrollo de una economía autónoma. (SEBRELI, 1975, p. 186)
\end{abstract}

O recurso ao argumento nacionalista inviabilizaria a prática revolucionária, pois impedia uma tomada de consciência de classe e sugeria que patrões e trabalhadores pudessem convergir no mesmo interesse, o nacional. Entretanto, a experiência da CGTA demonstrou o caráter fluído e maleável das experiências em contraposição à rigidez das definições. Pelos argumentos da central dissidente, pode-se confirmar “(...) que el problema es nacional"15 e a luta fundamental destes trabalhadores também se identificava com o combate à penetração estrangeira associada à expansão dos monopólios internacionais que, com interesses forâneos, obstaculizavam o desenvolvimento nacional, gerando sérias consequências sociais:

Es en el marco más vasto de la liberación nacional y la expulsión de todos los monopolios extranjeros que se desarrolla nuestra lucha. Los trabajadores afirmamos que mientras los monopolios permanezcan en el país, no existe solución nacional de los problemas del trabajo, la producción, la educación y el bienestar del pueblo.

\footnotetext{
${ }^{15}$ Semanário CGT n ${ }^{\circ} 22,26 / 06 / 1968$.

${ }^{16}$ Semanário CGT n ${ }^{\circ}$ 9, 27/06/1968.
}

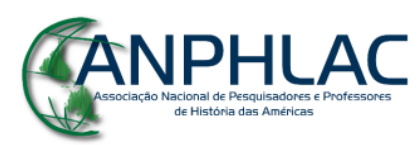

Revista Eletrônica da ANPHLAC, ISSN 1679-1061, №. 23, p. 238-260, Jul./Dez., 2017. http://revista.anphlac.org.br 
Una lucha que en primera instancia está dirigida a defender las condiciones de vida y de trabajo, pero indisolublemente ligada a la batalla por la conquista del poder para el pueblo, ya que en tanto los monopolios sigan gobernando no habrá satisfacción verdadera y estable de las reivindicaciones obreras y populares. ${ }^{17}$

Apesar de aparentemente confirmar a crítica levantada pelo intelectual argentino neste discurso, no qual a raiz dos problemas nacionais era vinculada apenas à opressão externa, o discurso nacionalista desenvolvido pelo grupo da CGTA contradizia em importantes aspectos a análise feita por Sebreli (1975). Do semanário CGT partia uma análise mais complexa do contexto vivido e que indicava um grau de conscientização importante dos trabalhadores a respeito dos fatores a serem considerados na dinâmica nacional e que contribuíam para a exploração do trabalho. Mais que uma imposição ofensiva e autoritária de fora, retórica clássica do discurso terceiromundista, reconheciase o papel dos atores internos - identificados com "el gobierno de los monopolios" Onganía e com "la vieja guardia entreguista"19 de lideranças sindicais organizadas na outra CGT - que, disfarçados em argumentos desenvolvimentistas, tentavam justificar a entrega do patrimônio nacional. Na engrenagem da exploração, a tríade oligarquia, governo militar e sindicalistas corrompidos mantinha o subdesenvolvimento do país e a consequente exploração e pauperização dos trabalhadores/povo. A panaceia desenvolvimentista era rechaçada pela CGTA e a conscientização desta frustração com as burguesias nacionais gerava um tom mais combativo e classista que aquele esperado por Sebreli dos discursos de libertação:

Todas las deficiencias y las virtudes del movimiento sindical se desnudaran en la Semana Trágica; pero más que nada se destacó la capacidad de sacrificio y el empuje combativo de la clase obrera, que emprendía por aquellos actos la difícil tarea de constituirse en la clase más avanzada de la nación, en un país donde la burguesía nacional mostró desde fines del siglo XIX una acentuada tendencia al compromiso con las clases dominantes, que la incapacitó para siempre para dirigir todo proceso realmente revolucionario. ${ }^{20}$

O trabalho de identificação da central com a ideia de "povo" vinha desde seus aspectos mais estruturais, ser a CGT “de los argentinos” excluía qualquer legitimidade

\footnotetext{
${ }^{17}$ Semanário CGT n ${ }^{\circ} 35,29 / 12 / 1968$.

${ }^{18}$ Semanário CGT n ${ }^{\circ}$ 9, 27/06/1968.

${ }^{19}$ Semanário CGT n ${ }^{\circ} 4,23 / 05 / 1968$.

${ }^{20}$ Semanário CGT n ${ }^{\circ} 36,09 / 01 / 1969$.
}

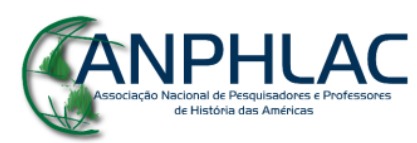

Revista Eletrônica da ANPHLAC, ISSN 1679-1061, №. 23, p. 238-260, Jul./Dez., 2017. http://revista.anphlac.org.br 
de outra central trabalhista e era reforçado pelas referências a "la CGT de los pobres" que fala "(...) el lenguaje de los oprimidos”" ideário nacional la clase obrera es depositaria" ${ }^{22}$ se complementava com a CGTA sendo a “(...) expresión real y legitima del movimiento obrero"23. A central de Raimundo Ongaro se construiu discursivamente como o centro de uma batalha que era nacional, anti-imperialista e cristã; representante máxima dos interesses nacionais e “(...) única y legitima válvula para la protesta popular de un pueblo que no acepta sometimientos" ${ }^{24} \mathrm{e}$ que havia contribuído para este "(...) alzamiento de la nacionalidad golpeada"25.

A "libertação nacional" só poderia ser realizada pelo povo e "(...) el movimiento obrero es la voluntad organizada del pueblo",26. A ideia de "povo" era vinculada necessariamente à classe trabalhadora que, neste momento, era encarnada pela facção combativa do movimento sindicalista, separada do gremialismo burocrático e colaboracionista:

\footnotetext{
Nosotros somos representantes de trabajadores, de oprimidos, de explotados, de desposeídos de todos los derechos. Somos los representantes de las ollas populares de Tucumán, de los mineros de Pan de Azúcar (...) ¿Cuándo hacemos la liberación del pueblo? ¿Somos hijos del pueblo, o somos hijos de - de qué? ${ }^{27}$
}

Esta lógica, na qual o ideário nacional é encarnado pelo movimento trabalhista organizado, é corroborada pelo tom vanguardista de uma luta de libertação nacional que só poderia ser encabeçada pelos próprios trabalhadores, “(...) el único sector del país no comprometido con el monopolio y la explotación”"28 e “(...) la única [clase] lo bastante lucida para hacer frente a esa brutal concentración de poder" ${ }^{29}$. Não houve, no discurso do sindicalismo combativo da CGTA, um recuo na ideia de luta de classes em prol de uma pretensa "luta entre nações"; pelo contrário, no caso argentino, houve uma valorização desta classe que, associada à herança política do peronismo, tornava os trabalhadores ponta de lança da luta de libertação nacional. A identificação dos

\footnotetext{
${ }^{21}$ Semanário CGT n ${ }^{\circ} 17,22$ a 29/08/1968.

${ }^{22}$ Semanário CGT n ${ }^{\circ} 40,06$ a 20/03/1968.

${ }^{23}$ Semanário CGT n ${ }^{\circ} 15,08$ a 15/8/1968.

${ }^{24}$ Semanário CGT n ${ }^{\circ} 44,22 / 05 / 1969$.

${ }^{25}$ Semanário CGT n ${ }^{\circ}$ 51, 23/09/1969.

${ }^{26}$ Semanário CGT n ${ }^{\circ}$ 1, 01/05/1968.

${ }^{27}$ Semanário CGT n ${ }^{\circ} 25,17 / 10 / 1968$.

${ }^{28}$ Semanário CGT n ${ }^{\circ} 22,26 / 06 / 1968$.

${ }^{29}$ Semanário CGT n ${ }^{\circ} 19,05 / 09 / 1968$.
}

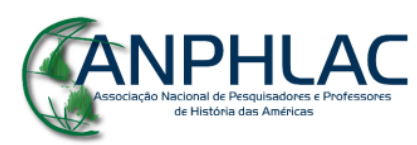

Revista Eletrônica da ANPHLAC, ISSN 1679-1061, №. 23, p. 238-260, Jul./Dez., 2017. http://revista.anphlac.org.br 
trabalhadores com o peronismo reforçava este caráter popular do movimento organizado exatamente no momento em que Perón atraía os movimentos de libertação por seu conteúdo altamente nacionalista e anti-imperialista, sendo empurradas para debaixo do tapete as críticas que haviam embalado anteriormente as classes médias que, neste momento, aderiam ao peronismo.

A convergência da classe média, historicamente antiperonista, ao peronismo é um tema de farta bibliografia ${ }^{30}$. Compreender este processo que levou a assimilação das camadas médias pelo peronismo passa pela recepção do discurso terceiromundista que na Argentina se colou naturalmente à Perón e sua terceira posição. O papel do peronismo como parte das lutas de libertação foi extremamente valorizado pela esquerda nacional que, no impacto da Revolução Cubana (1959) sobre o continente, viu a possibilidade de revoluções fora dos moldes delineados pelo partido comunista e encontrou em movimentos como o peronismo um caminho nacional para o socialismo. Já apontava Juan José Sebreli (1975, p. 81):

\begin{abstract}
La fascinación de ciertas izquierdas por los regímenes bonapartistas no es un hecho nuevo sino un tipo de desviacionismo ya clásico (...) y surge cada vez que el Estado, para salvar al capitalismo, se ve obligado a intervenir en la economía alentando de ese modo en algunos intelectuales las ilusiones del "socialismo de Estado".
\end{abstract}

O desvio teórico em relação à esquerda estava assentado em valorizar a figura do Estado, no caso peronista altamente personalista, como uma ponte para o socialismo. Para Sebreli, a ilusão de um "socialismo" nacional não era novidade e encaixava em uma estratégia do nacionalismo burguês para frear o avanço da classe trabalhadora a uma revolução que de fato ensejasse uma mudança no modo de produção. A possibilidade de um "socialismo de Estado" era tão desalentadora para o autor tanto quanto o era outra variante dos movimentos de libertação, o "capitalismo de Estado". O processo de estatização das empresas estrangeiras como forma de alcançar a independência econômica e, portanto, a libertação nacional como passo prévio para a socialização se explicava, segundo o intelectual argentino, por outra confusão teórica. A

\footnotetext{
30 Para citar algumas obras mais recentes: ADAMOVSKY, Ezequiel. Historia de la clase media argentina: apogeo y decadencia de una ilusión, 1919-2003. Buenos Aires: Planeta, 2009 e SPINELLI, María Estela. De antiperonistas a peronistas revolucionários. Buenos Aires: Sudamericana, 2013.
}

\title{
GANPHLAC
}

Revista Eletrônica da ANPHLAC, ISSN 1679-1061, №. 23, p. 238-260, Jul./Dez., 2017. http://revista.anphlac.org.br 
equivocada interpretação terceiromundista da teoria marxista corroborava seu caráter mítico burguês:

La confusión entre nacionalización y socialización reside una vez más en la teoría hegeliana del Estado. Si el Estado estuviera efectivamente por encima de las clases, nacionalizar, es decir, dar a la nación significaría dar a la sociedad, pero la nación se divide en clases, y el Estado representa a la clase dominante, por lo tanto, nacionalizar significa dar a la clase dominante y expropiar a la clase dominada. El capitalismo de Estado no es, por lo tanto, una etapa previa al socialismo, sino una forma de opresión y explotación de los trabajadores. (SEBRELI, 1975, 97)

Retornando ao estudo de caso, a experiência sindical da CGTA, o debate econômico difundido no semanário confirmava esta característica terceiromundista delineada por Sebreli. A nacionalização foi uma proposta reiterada como passo prévio para um programa político que se propunha revolucionário ${ }^{31}$. Era explícita também a conclusão que se chegou do "capitalismo de Estado" como uma etapa necessária aos países de Terceiro Mundo em seu percurso revolucionário:

Lo que queremos decir con esto es que históricamente las estatizaciones obedecen a muchas razones. Pero hay algo de común que las unifica y que es sumamente importante. Algo que las hace deseable para el pueblo y repulsiva para los explotadores. Aunque débil, aunque tenue, son un anticipo de un orden más justo, de una gestión común de los medios de producción. ${ }^{32}$

Havia um reconhecimento de que o processo de nacionalização podia atender a diversos interesses que não necessariamente o "nacional"; porém, considerava-se a possibilidade de fazer a transição do nacionalismo ao socialismo. Esta lógica não era fruto apenas da identificação da CGTA com o socialismo nacional terceiromundista, mas ia ao encontro da cultura política peronista, que reiteradamente se remetia às estatizações dos anos justicialistas como uma etapa no processo de libertação nacional ${ }^{33}$.

\footnotetext{
${ }^{31}$ O Programa $1^{\circ}$ de mayo (1968), programa político da CGTA divulgado no semanário $\mathrm{n}^{\circ} 1$, destacava que: "los sectores básicos de la economía pertenecen a la nación. El comercio exterior, los bancos, el petróleo, la electricidad, la siderurgia y los frigoríficas deben ser nacionalizados”. Anterior a este programa, outros dois documentos ligados aos setores mais combativos do sindicalismo argentino e tomados como documentos históricos pela CGTA já pleiteavam esta proposta: "Política energética nacional; para ello se hace indispensable la nacionalización de las fuentes de energía (...) nacionalización de los frigoríficas extranjeros" (La Falda, 1957); "1. Nacionalizar todos los bancos y establecer un sistema bancario estatal y centralizado (...) 3. Nacionalizar los sectores claves de la economía: siderurgia, electricidad, petróleo, frigoríficas." (Huerta Grande, 1962).

32 Semanário CGT n 29, 14/11/1968.

33 “A política peronista foi caracterizada por um forte estímulo à participação do Estado na condução e regulamentação da economia (...) houve uma nacionalização generalizada dos investimentos estrangeiros
}

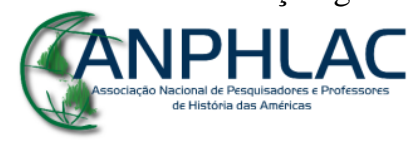

Revista Eletrônica da ANPHLAC, ISSN 1679-1061, №. 23, p. 238-260, Jul./Dez., 2017. http://revista.anphlac.org.br 
Indica, deste modo, que, em um contexto de marginalização do movimento e recrudescimento do governo militar, a associação entre "Terceiro Mundo" e a "terceira posição" de Perón como expressão nacional de um movimento de libertação foi eficaz em pintar de revolucionário um movimento que sempre tendeu ao reformismo. Como aponta Sebreli (1975, p. 95), a falha grave na interpretação peronista era que “(...) Perón considera que el capital y el trabajo son factores igualmente necesarios de la producción, no se trata pues de revolución social sino de "justicia social"”. O peronismo não partia de uma crítica do sistema capitalista, mas de uma aliança mais justa entre o capital e trabalho:

La relación entre el capital y el trabajo permanece inmutable, sea el capital privado o del Estado. Para el obrero es exactamente igual ser explotado por el Estado o por la burguesía. (SEBRELI, 1975, p. 96)

Contudo, a experiência mais uma vez revela outras configurações fora dos limites das definições. A CGTA aderiu ao discurso de estatização como caminho para a socialização, porém o fez a partir de outras perspectivas que lançam luz sobre o discurso revolucionário que surgiu de suas fileiras. Nos números 29 e 30 do semanário CGT foram publicados artigos a respeito do papel da nacionalização como etapa para a libertação nacional. Todavia, cabe destacar o que a diferenciava daquilo que Sebreli observou em outros movimentos que seguiam a mesma tendência. Como resultado do recorte classista que distinguiu a CGTA de outros movimentos de libertação nacional, o debate a respeito das nacionalizações veio acompanhado de um chamado a "participación obrera":

Debemos hacernos la pregunta. ¿Quiénes habrán de realizarlas [estatización]? El Estado y el pueblo con sus organizaciones sindicales unidas en un vigoroso frente nacional. La responsabilidad, la tarea fundamental, corresponde a las organizaciones sindicales. (...) La participación de las organizaciones sindicales en las organizaciones estatales es una urgente necesidad. $^{34}$

(...) Isso se revestiu de grande importância simbólica, expressa na fórmula da Independência Econômica, proclamada solenemente em Tucumán, em 9 de julho de 1947. Somaram-se às ferrovias, os telefones, a empresa de gás e algumas companhias de eletricidade do interior (...) Assim a nacionalização da economia e seu controle pelo Estado foram uma das chaves da nova política econômica" (ROMERO, 2006, p. 102).

${ }^{34}$ Semanário CGT n 30, 21/11/1968.

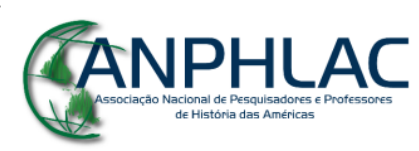

Revista Eletrônica da ANPHLAC, ISSN 1679-1061, №. 23, p. 238-260, Jul./Dez., 2017.

http://revista.anphlac.org.br 
No direcionamento da ação, a CGTA não deixou de lado o tom classista de um embate em que o protagonista era a classe trabalhadora, única depositária do sentimento nacional. Neste ponto, o projeto delineado pela central de Ongaro se adequava à exceção de Sebreli a respeito do peso das nacionalizações como um caminho para o socialismo: "La estatización no es la socialización, en tanto que la clase trabajadora no tenga ningún control sobre el Estado y, por conseguiente, sobre su propio trabajo" (SEBRELI, 1975, p. 97). Essa consciência de tomada de poder pela classe trabalhadora foi uma constante no discurso da CGTA, que não partia da concepção idealista do Estado. O Estado por si só não era a manifestação do interesse nacional nem depositário de um potencial revolucionário, só o seria caso fosse tomado pelo povo e colocado a serviço dele (no caso, "povo", como já explanado acima, significava diretamente trabalhadores). Houve na entidade um debate mais aprofundado das condições nacionais e uma tradução do discurso terceiromundista que apresentou características profundamente ligadas à tradição da esquerda marxista em que, indiscutivelmente, o ator político da revolução era a classe trabalhadora.

\section{Conclusão}

Discursos políticos ensejam práticas concretas de pensamento que nos levam a compreender a relação entre as condições de produção do saber e as condições para a ação política. Para analisar o discurso peronista, Eliseo Verón e Silvia Sigal (2014, p. 15) observaram que "como todo comportamiento social, la acción política no es comprensible fuera del orden simbólico que la genera y del universo imaginario que ella misma engendra dentro de un campo determinado de relaciones sociales". Deste modo, compreender a concepção terceiromundista como forma de acesso à dinâmica de organizações revolucionárias no conturbado contexto político latino-americano do pósguerra é exercício essencial de análise.

Em 1975, no livro Tercer Mundo, mito burguês, Juan José Sebreli (1975) analisou o tom reformista que encerrava a concepção terceiromundista de revolução. A ideia de "libertação nacional" e a terceira via identificada com o "socialismo nacional" seriam a culminância de uma análise equivocada do processo histórico e da dinâmica socioeconômica. Segundo o autor, o nacionalismo característico desta tendência levou à

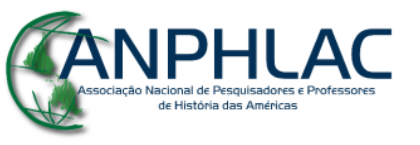

Revista Eletrônica da ANPHLAC, ISSN 1679-1061, №. 23, p. 238-260, Jul./Dez., 2017. http://revista.anphlac.org.br 
subordinação da luta de classes à luta entre nações na qual a retórica anti-imperialista retirou do proletariado seu papel de "universal concreto" e o direcionou para o povo/nação. Merleau-Ponty advertia que:

Un socialismo, si es 'nacional', deja de ser un socialismo; los burgueses de todos los países han comprendido muy bien que agregando al socialismo ese adjetivo, se le quita todo lo que podía tener de inquietante. (SEBRELI, 1975, p. 26)

Ou seja, o paradoxo de uma "internacional nacional" atendia a interesses espúrios aos da classe trabalhadora derivados de um nacionalismo burguês que seria para o autor o traço mais marcante da característica reformista do discurso terceiromundista.

No entanto, vários movimentos que aderiram à luta armada no contexto de fechamento político em diferentes países da região endossaram suas ações a partir da perspectiva de "Terceiro Mundo" ou de uma "via nacional para o socialismo". Na América Latina, as condições políticas para a recepção do terceiromundismo ia ao encontro de uma cultura política regional marcadamente nacionalista e anti-imperialista que via nas duas superpotências o perigo da dominação estrangeira. No caso argentino, já sinalizada pela "terceira posición" de Juan D. Perón, a assimilação do "Terceiro Mundo" inevitavelmente tomou o movimento peronista como uma expressão nacional do caminho socialista ${ }^{35}$. Neste ponto, tomou-se como paradigma de análise a experiência política da CGT de los Argentinos (CGTA), dissidência sindical peronista que posteriormente alimentou as fileiras do peronismo revolucionário e das organizações armadas na década de 1970. Frente às críticas levantadas por Sebreli, a CGTA - por seu papel no contexto específico de rearticulação do movimento peronista devido às crises internas e ao recrudescimento da ditadura de Juan C. Onganía (19661970) - é um estudo de caso profícuo para compreender a capacidade de reinterpretação dos discursos vinculada às condições que os geraram.

Sendo uma entidade sindical, portanto representativa de classe, as condições para a recepção e tradução do terceiromundismo pelos trabalhadores organizados na CGTA apresentaram peculiaridades que revelaram a relação entre discurso e ação

\footnotetext{
35 "Para nosotros los justicialistas el mundo se divide hoy en capitalistas y comunistas en pugna: nosotros no somos ni lo uno, ni lo otro." (PERÓN, Juan Domingo. La fuerza es el derecho de las bestias. Villegas, 1956)
}

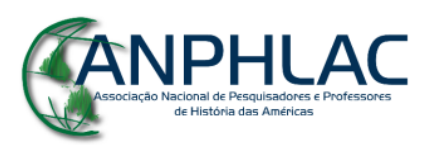

Revista Eletrônica da ANPHLAC, ISSN 1679-1061, №. 23, p. 238-260, Jul./Dez., 2017. http://revista.anphlac.org.br 
política. Foi demonstrado que, apesar de se situar como um movimento de "libertação nacional", a premissa de classe não escapou ao grupo e a forma de alimentar a teoria, analisada por meio do semanário CGT, contornou certos problemas apontados por Sebreli (1975). Em contraposição ao nacionalismo burguês, descrito pelo intelectual argentino como uma “(...) confianza exagerada en las burguesias nacionales”, a CGT concebeu o papel da classe trabalhadora como sujeito universal e seu protagonismo no processo revolucionário. A construção discursiva do semanário levou à associação direta entre povo e classe trabalhadora, diferentemente da ideia povo/nação tipicamente associada aos discursos de libertação nacional que elevavam as elites nacionais ao papel de classe revolucionária em um projeto de desenvolvimento independente. Chegava-se à conclusão de que “(...) la burguesía nacional mostró desde fines del siglo XIX una acentuada tendencia al compromiso con las clases dominantes, que la incapacitó para siempre para dirigir todo proceso realmente revolucionario"36, portanto, na Argentina, esse processo teria como vanguarda os trabalhadores, classe verdadeiramente representativa do "nacional". É possível constatar que, corroborando a descrição de Sebreli, o argumento central era ainda a ideia do "nacional". Entretanto, a tradução do discurso passava por outra construção que associava o movimento trabalhista como “(...) la voluntad organizada del pueblo"37 e, deste modo, reivindicava o protagonismo dos trabalhadores neste processo. Este trabalho de associação entre o "nacional" e a classe trabalhadora foi adjacente a toda proposta da CGTA que, inclusive, no plano econômico pensava o nacionalismo a partir de uma perspectiva classista.

Para Juan J. Sebreli (1975) o nacionalismo econômico que derivava da premissa de que a nacionalização era uma etapa prévia à socialização foi resultado de um desvio teórico que, alimentado pelo idealismo do Estado como representativo da vontade nacional, impedia uma crítica profunda do capitalismo e reforçava seu caráter mítico burguês. A CGTA aderiu abertamente à estatização das empresas estrangeiras como um caminho para a socialização; a identificação com o peronismo e a ideia de soberania política e independência econômica do período justicialista embasaram o argumento da possibilidade de uma revolução social que cada vez mais se identificava com o retorno do líder exilado e a ação do Estado. Dentro destas possibilidades de interpretação, as

\footnotetext{
${ }^{36}$ Semanário CGT n ${ }^{\circ} 36,09 / 01 / 1969$.

${ }^{37}$ Semanário CGT n ${ }^{\circ}$, 01/05/1968.
}

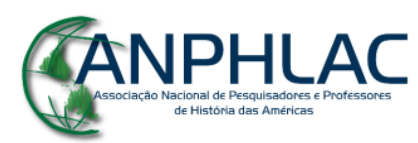

Revista Eletrônica da ANPHLAC, ISSN 1679-1061, №. 23, p. 238-260, Jul./Dez., 2017. http://revista.anphlac.org.br 
condições de produção do discurso político emanado da CGTA, cujo cerne da questão nacional era diretamente ligado ao papel da classe trabalhadora, possibilitou outra leitura do caminho para a socialização. A estatização era uma proposta que só se tornaria eficaz com a "participación obrera" já que, precedente a esta etapa, estaria a tomada de poder político pelos trabalhadores; a crítica anticapitalista era reiterada como uma "missão natural" destes que "(...) no reprueban una forma determinada del capitalismo: las cuestiona a todas" 38 e que entendia que "Esa felicidad [de los trabajadores] es imposible mientras el sistema explotador capitalista no sea destruído hasta sus cimientos" ${ }^{, 39}$.

Para compreender este recorte classista do discurso de libertação nacional produzido pela CGTA foi preciso conhecer o espaço de produção/tradução deste discurso. Fazendo convergir diferentes setores da resistência à ditadura militar de Onganía, a CGTA atraiu para suas fileiras setores que anteriormente haviam se identificado com a esquerda marxista. Na conjuntura argentina, a identificação entre os trabalhadores e o peronismo, a partir de 1943, havia retirado da esquerda tradicional seu protagonismo político entre os setores mobilizados. Com a proscrição do movimento após a Revolução Libertadora em 1955, a permanência do peronismo entre as classes populares revelou para diferentes setores da esquerda - geralmente associada à classe média e que anteriormente havia engrossado o coro antiperonista - a necessidade de reconsiderar o peronismo como um caminho inevitável. Classe trabalhadora e peronismo funcionavam como sinônimos político-ideológicos. A participação destes setores corrobora aquilo que Sebreli afirmou como sendo uma consequência do terceiromundismo, a conformação de uma espécie de semimarxismo em que certos aspectos da teoria são assimilados em uma variante nacional, porém ineficaz pela negação da tese central: a universalidade da revolução socialista. Na crítica explanada por Sebreli, cabe destacar a consequência direta da associação entre o marxismo e movimentos nacionais, como foi o caso do peronismo na Argentina:

También el ala izquierda de los propios movimientos nacionalistas burgueses, integrada en general por pequeña burguesía radicalizada, alienta la ilusión de impulsar por propia acción la transición del nacionalismo hacia el socialismo.

\footnotetext{
${ }^{38}$ Semanário CGT n ${ }^{\circ}$ 10, 04/07/1968.

${ }^{39}$ Semanário CGT n ${ }^{\circ} 37,23 / 01$ a 06/02/1969. 
El fracaso histórico de John William Cooke en el plano político, de Amado Olmos, Alberto Belloni y otros en el plano sindical, al tratar de cumplir el papel de vanguardia del proletariado pero sin poder romper con la dirección burguesa del peronismo, es un ejemplo clásico de que ese camino no lleva a ninguna parte. (SEBRELI, 1975, p. 81)

A tradução classista adotada pela CGTA daqueles que falavam do "Terceiro Mundo" não foi capaz de superar o personalismo estrutural do peronismo. Apesar de contornar as características advertidas por Sebreli como desvios teóricos, a experiência da CGTA foi exemplar para a conclusão do autor. A "revolución desde abajo" preconizada por alguns setores radicalizados e a tentativa de converter o binômio Perón/povo para o correspondente trabalhadores/povo foram obstaculizadas pela própria natureza destes movimentos. A tomada de consciências de classe ainda era um feito de vanguarda e se a cúpula pensante e estruturante do discurso político era marxista, a base era peronista.

\section{Referências Bibliográficas}

\section{Corpus documental}

Semanário da CGT (CGTA) - 55 números. Digitalizados pela Federación Gráfica Bonaerense. Disponível em: http://www.cgtargentinos.org/

\section{Bibliografia}

ADAMOVSKY, Ezequiel. Historia de la clase media argentina: apogeo y decadencia de una ilusión, 1919-2003. Buenos Aires: Planeta, 2009.

BALVÉ, Beba; BALVÉ, Beatriz. El '69: huelga política de masas: RosariazoCordobazo-Rosariazo. Buenos Aires: Contrapunto, 1989.

BARTOLETTI, Julieta. La CGT de los argentinos y los dilemas de la izquierda peronista. Salta: Revista Escuela de Historia, vol. 10, nº 2, 2011.

BERSTEIN, Serge. A cultura política. In: RIOUX, Jean-Pierre; SIRINELLI, JeanFrançois (Eds.). Para uma história cultural. Lisboa: Estampa, 1998.

DAWYD, Darío. Sindicatos y Política en la Argentina del Cordobazo. El peronismo entre la CGT de los Argentinos y la reorganización sindical (1968-1970). Buenos Aires: Editorial Pueblo Heredero, 2011.

KOZEL, Andrés; GROSSI, Florencia; MORONI, Delfina (Coords.). El imaginario antiimperialista en América Latina. Ciudad Autónoma de Buenos Aires: Ediciones del

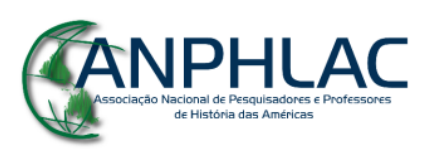

Revista Eletrônica da ANPHLAC, ISSN 1679-1061, №. 23, p. 238-260, Jul./Dez., 2017.

http://revista.anphlac.org.br 
Centro Cultural de la Cooperación Floreal Gorini; Ciudad Autónoma de Buenos Aires: CLACSO, 2015.

MANIFESTO dos Bispos do Terceiro Mundo (1968). Disponível em http://www.ruinasdigitales.com/cristianismoyrevolucion/cyrmanifiestodeobisposdeltercermundo 66/. Acesso em: 20 de janeiro de 2018.

PERÓN, Juan Domingo. La fuerza es el derecho de las bestias. Villegas, 1956.

ROMERO, Luis Alberto. História Contemporânea da Argentina. Rio de Janeiro: Jorge Zahar, 2006.

ROTONDARO, Rúben. Realidad y cambio en el sindicalismo. Buenos Aires: Pleamar, 1971.

SEBRELI, Juan Jose. Tercer Mundo Mito burgués. Buenos Aires: Siglo Veinte, 1975.

SOTELO, Luciana. La CGT de los Argentinos: entre el movimiento sindical y el movimiento político. XI Jornadas Interescuelas/ Departamentos de Historia, Tucumán, 19 al 21 de Septiembre de 2007.

SPINELLI, María Estela. De antiperonistas a peronistas revolucionarios. Buenos Aires: Sudamericana, 2013.

\section{GANPHLAC}

Revista Eletrônica da ANPHLAC, ISSN 1679-1061, №. 23, p. 238-260, Jul./Dez., 2017.

http://revista.anphlac.org.br 